\title{
Transferência Cultural e Tradução na Internet
}

\section{Tinka Reichmann \\ Universidade do Sartre}

Este artigo analisa alguns aspectos da transferência cultural e da tradução na Internet. Através de exemplos que mostram a complexidade do trabalho de tradução de hipertextos, discute-se as exigências específicas relativas à tradução de hipertextos

This article analyses some aspects of cultural transfer and translation on the Internet. The specific demands on the translation of hypertexts are illustrated by examples showing the complexity of the hypertext translators' work.

\section{Introdução}

Neste artigo pretendo esboçar as características da transferência cultural nos novos meios eletrônicos de comunicação e a tradução de hipertextos. Num projeto na Faculdade de Direito da Universidade do Sarre, que publica informações e materiais jurídicos regularmente na Internet, foram criadas "seções" nas quais estas informações são traduzidas integral ou parcialmente do alemão para outros idiomas. Hoje em dia, é um projeto jurídico Internet multilíngüe de renome na Alemanha (www.jura.uni-sb.de).

Fui encarregada de realizar as traduções deste projeto para o português. Desta experiência surgiram as questões centrais deste trabalho:

a. Quais são as características técnicas e lingüísticas dos hipertextos?

b. Como a Internet pode ajudar a superar barreiras culturais?

c. Quais aspectos devem ser considerados na tradução de hipertextos e na produção de páginas multilíngües na Internet?

\section{Características dos hipertextos}


A Internet oferece diferentes serviços, como a World Wide Web, Email, FTP etc. Optei por usar a expressão "Internet" neste ensaio por ser mais corriqueira, apesar de referir-me, muitas vezes, à WWW. Estes meios eletrônicos estão transformando a linguagem e os textos e, portanto, o objeto central da tradução.

\section{Hipertextos: descrição lingüística}

Os textos típicos da Internet, os chamados hipertextos, distinguem-se dos textos tradicionais impressos em papel pela existência de vínculos internos e externos (links). Os vínculos não são um simples complemento de um texto linear, mas são parte integrante do texto.

Os hipertextos são não-lineares porque é possível saltar de uma unidade de hipertexto para uma outra através destes vínculos. O leitor constitui assim o seu texto individual, que pode muito bem divergir do texto de outro leitor. Em outras palavras: o hipertexto não possui uma estrutura rígida e pré-estabelecida. A vantagem disto é que o leitor pode selecionar e reunir as informações dos hipertextos relevantes de acordo com os seus conhecimentos e interesses. Apesar de existirem também hipertextos não-eletrônicos, o termo "hipertexto" tornou-se conhecido através da Internet e é usado geralmente como sinônimo de "hipertexto eletrônico".

Segundo os resultados de pesquisas na área da lingüística do hipertexto (Todesco 1998, Storrer 2000, Marcuschi 2001), o hipertexto pode ser definido como um texto: a) não-linear e não-seqüencial (esta tida como a característica principal do hipertexto), b) eletrônico e c) multisemiótico (linguagem escrita, ícones, elementos de áudio e vídeo).

Marcuschi (2001) enumera ainda a topografia, a fragmentariedade, a acessibilidade ilimitada, a interatividade e a iteratividade como características intrínsecas dos hipertextos.

\section{A relação entre autor e leitor de hipertextos}

Outra diferença fundamental entre textos lineares e hipertextos refere-se à situação do autor em relação ao texto e em relação ao leitor. $\mathrm{O}$ autor de hipertextos só produz módulos de texto sem determinar necessariamente uma seqüência. Pode planejar uma seqüência desejada, mas isto não significa que o texto será lido nesta ordem. 
O autor de um hipertexto em geral está consciente que o leitor chegou ao seu texto através de uma pesquisa por palavras-chave numa ferramenta de busca. Isto significa que estes leitores têm, muitas vezes, um conhecimento prévio que querem aprofundar. $\mathrm{O}$ autor está preparado para que o texto seja lido de maneira pontual e não por inteiro.

O leitor, por sua vez, também não é mais um simples receptor passivo do texto que é obrigado a seguir uma sequiência inflexível, mas pode participar ativamente na construção do texto.

Porém, se é o leitor que decide aquilo que quer ler, o esquema clássico da comunicação com um emissor que codifica uma mensagem e um receptor que decodifica esta mensagem não é adequado para descrever a comunicação de hipertextos.

$\mathrm{O}$ receptor não é mais um agente passivo, mas sim um tipo de co-autor que seleciona os módulos de texto ativamente: a leitura torna-se "simultaneamente uma escritura" (Marcuschi 2001:28). Adaptando o esquema tradicional da comunicação aos hipertextos, este poderia ser visualizado assim:

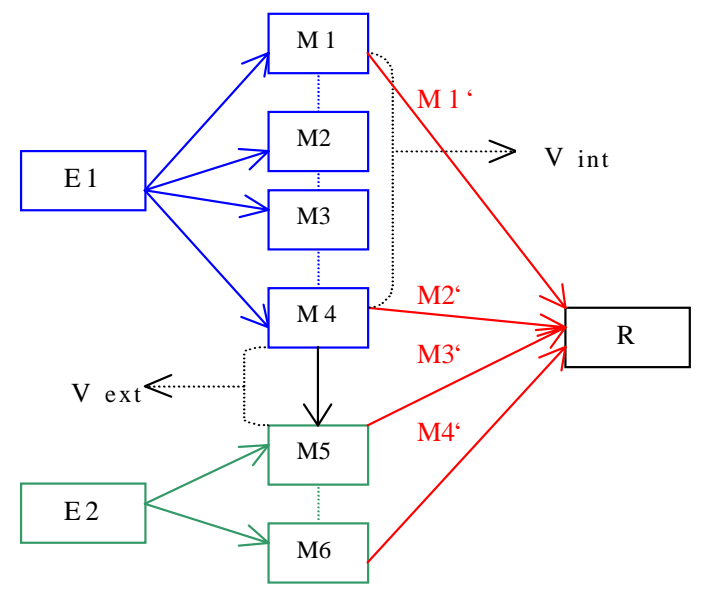

Fig.1: Esquema da comunicação de hipertextos

$\mathrm{E}=$ Emissor, $\mathrm{M}=$ Mensagem (aqui: módulos de hipertexto), $\mathrm{M}^{`}$ : Mensagem selecionada pelo receptor, V= Vínculo de hipertexto (link), $\mathrm{R}=$ Receptor

\section{Coerência e coesão}


A contectividade é uma das propriedades fundamentais da textualidade e pode ser dividida em conectividade conceptual (coerência) ou conectividade seqüencial (coesão) (Mateus et al. 1992). A seqüencialização enquanto processo lingüístico para estabelecer a coesão textual torna-se problemática ao considerar que o hipertexto é um texto nãoseqüencial. Podemos entender a seqüencialização de hipertextos não como a seqüência de leitura pré-estabelecida pelo autor, mas como a seqüência de leitura real do leitor-navegador.

A coesão pode estar perturbada, p.e. em caso de links para páginas de Internet com endereço errado ou desatualizado. Este problema não é raro; problemas técnicos também podem levar à falta de acesso temporário a determinadas páginas da Web. Todos estes problemas de coesão podem levar a dificuldades de estabelecimento da coerência.

Em textos lineares, a seqüencialização é um instrumento importante para assegurar a coerência, e através desta, a qualidade comunicativa de um texto. Apesar de ser o leitor que estabelece a coerência tanto em textos lineares como em hipertextos, as condições para tanto são bastante diferentes: a deslinearização limita a possibilidade de o autor prever os elementos que o leitor necessita para estabelecer a coerência. É legítimo, portanto, questionar se o conceito de coerência da lingüística textual é suficientemente amplo para descrever a coerência em hipertextos, levando em consideração o papel ativo do leitor na recepção do texto.

\section{Transferência cultural na Internet}

À primeira vista, a Internet parece estar totalmente dominada pela língua inglesa. Esta impressão certamente é correta em relação aos aspectos técnicos da Internet. Mas foi constatado também que há cada vez mais usuários da Internet de outros idiomas que encontram um espaço de comunicação na rede. Foi demonstrado que a porcentagem de usuários da Internet de outros idiomas em 1999 estava em torno de $42 \%$ e tendia a aumentar cada vez mais (Eckkrammer et al. 2000). Estes usuários preferem usar sua língua materna para a publicação e pesquisa na rede.

A Internet está sendo utilizada cada vez mais como plataforma da transferência cultural, colocando uma grande variedade de informações à disposição dos usuários. Outra tendência é que há cada vez mais usuários 
de idiomas "menores" (na Europa p.e. seria o norueguês, na América Latina o guarani).

A adaptação consciente das páginas de Internet comerciais à cultura dos respectivos países também demonstra a importância das características nacionais (e portanto culturais) na economia. A tendência da globalização levou paradoxalmente também a uma corrente de localização.

Páginas multilíngües como o projeto em questão contribuem para um maior intercâmbio de informações e ajudam a superar as barreiras culturais através da tradução. Dificilmente haveria um jornal de notícias impresso em 11 idiomas diferentes que pudesse ser tão atual, tão facilmente acessível e tão econômico como este serviço na Internet.

Outra vantagem das páginas multilíngües na Internet é a possibilidade e a facilidade de diálogo direto com os autores. A equipe redacional do projeto recebe emails diariamente com perguntas, comentários e pedidos de informação de muitos lugares do mundo. As diversas seções geralmente animam os usuários a formular suas perguntas ou seus comentários na sua respectiva língua materna.

Considerar as características específicas de cada cultura, imprescindível na tradução, é um desafio especial no caso dos hipertextos, porque as páginas de Internet multilíngües exigem uma maior fidelidade às estruturas do texto. Gil (1999a:290) utiliza o conceito da aproximação de Koller para descrever a realização da "arte de unir a proximidade alcançável à distância inevitável”. Para o hipertexto, a aproximação significa manter a maior similaridade estrutural permitida no texto de chegada.

\section{Aspectos específicos da tradução de hipertextos}

Os aspectos que devem ser considerados ao traduzir hipertextos não diferem muito das já conhecidas nos textos lineares. Novas são, no entanto, algumas soluções que permitem superar algumas dificuldades que gostaria de demonstrar a seguir.

Fidelidade às estruturas do texto

As páginas de Internet multilíngües procuram estruturar seus textos nas diferentes línguas da maneira mais similar possível. Esta 
rigidez e o fato de o texto dos links ser parte integrante do hipertexto limitam as possibilidades de modificar as estruturas do texto. O realce gráfico dos links nem sempre é compatível com a estrutura da língua.

A página principal do projeto mencionado tem um lay-out bastante complexo que ilustra a restrição gráfica dos textos para as traduções. Trata-se de um projeto alemão que oferece as informações mais importantes em outros idiomas. Através disso, pretende-se oferecer informações a um público muito variado, mas os textos traduzidos estão limitados pelo lay-out da página principal alemã. Há, portanto, tecnicamente pouca flexibilidade para as traduções devido ao espaço gráfico. Mas também por motivos da identidade corporativa a tradução deve manter a maior fidelidade estrutural possível ao original: www.jura.uni-sb.de/portugues/.

\section{Integração de links complementares}

O texto de partida pressupõe no leitor um determinado conhecimento prévio que está implícito no texto. Já que o leitor da línguaalvo supostamente não possui este conhecimento prévio, este deve ser explicitado na tradução para manter a coerência do texto traduzido. Nos hipertextos existe a possibilidade de integrar links complementares analogamente a notas de rodapé ou explicações entre parênteses em textos lineares, com a diferença que os links tornam a leitura mais fluente para o usuário do que notas.

Além disso, esta técnica torna a leitura do texto mais eficiente (cf. Beaugrande et al. 1981:11). O texto do link pode p.e. ser uma tradução literal de uma instituição apontando para a página principal desta, onde o usuário que não possui o conhecimento sobre a instituição recebe as informações necessárias. Aquele usuário que já possuir este conhecimento não perde tempo com explicações desnecessárias. Esta "economia" pode ser muito útil para compensar as restrições dadas pelo lay-out.

Assim é aproveitada uma característica dos hipertextos que permite ao leitor de selecionar as partes que lhe interessam. Por exemplo, na notícia www.jura.uni-sb.de/portugues/ndw2002/ndw009.htm foi integrado um link que não constava no original e que aponta para uma instituição talvez desconhecida ao leitor estrangeiro. Este tem a possibilidade de acessar informações evidentes para o público alemão, o que permite realizar a transferência cultural da melhor forma possível. 


\section{Adaptação dos links}

Os links das traduções devem ser adaptados na medida do possível na língua-alvo. Há três casos a serem considerados para a adaptação dos links:

a) Se no texto de partida houver um link para uma página multilíngüe que contiver a língua-alvo, o link da tradução deve apontar para a versão desta página na língua-alvo. O link para a página alemã de uma agência européia foi modificado na tradução, apontando para a página em português: www.jura.uni-sb.de/portugues/ldw2001/ldw24.htm.

b) Se um link de um texto de partida apontar para uma página multilíngüe que não contiver a língua-alvo, deve ser tomada uma decisão para qual versão desta página o link da tradução deve apontar. Sempre que o link apontar para páginas disponíveis em alemão, inglês e francês, foi tomada a decisão pragmática de adaptar os links para apontarem para páginas em inglês, como no exemplo a seguir: www.jura.uni-sb.de/portugues/ldw2002/ldw02.htm.

c) Se o texto de partida contiver um link que aponte para uma página que só existe na língua-fonte, não resta outra possibilidade senão deixar o link apontando para esta página: www.jura.uni-sb.de/portugues/ldw2002/ldw03.htm

Estas decisões requerem, além da capacidade tradutória, o domínio da técnica de adaptação dos links. Além disso, requer um trabalho de pesquisa sobre os textos para os quais os links apontam que não é necessariamente visível no resultado final, pois o tradutor realiza a sua obrigação de manter a coerência do texto através da adaptação dos links.

\section{Resultados}

Resumindo os resultados da experiência deste projeto e sem pretender que o presente ensaio possa oferecer respostas definitivas e exaustivas, afirmo que a tradução de hipertextos vai além da tradução de textos lineares. Os hipertextos são, em grande parte, textos eletrônicos e não-lineares que contêm elementos de multimídia. Os leitores de hipertextos exercem um papel mais ativo na comunicação que os leitores de textos lineares. 
Quanto aos novos meios de comunicação, mencionei que, apesar do domínio da língua inglesa, as outras línguas estão conquistando um espaço importante. A Internet é uma plataforma de comunicação mundial em que a tradução é o instrumento fundamental para a realização da transferência cultural.

As características dos hipertextos aqui esboçadas devem, a meu ver, ser consideradas e aproveitadas no processo de tradução, pois oferecem várias possibilidades novas para superar dificuldades de tradução em comparação com textos lineares.

A inflexibilidade estrutural (isto é, gráfica) que limita a atuação do tradutor de hipertextos pode ser compensada e superada pela habilidade do tradutor de adaptar ou incluir links nas suas traduções. Isto torna a leitura dos textos mais fluente devido à integração dos links no texto com a possibilidade de fornecer informações complementares na medida do desejado pelo leitor. Além disso, o tradutor pode facilitar o estabelecimento da coerência através da adaptação dos links. $O$ tradutor colabora para que a leitura do texto se torne mais econômica e eficiente adequando-se aos conhecimentos prévios do leitor, facilitando assim a transferência cultural.

Baseado nisto, ficou comprovado que a tradução de hipertextos é mais complexa que a tradução de textos lineares, ampliando o perfil do tradutor profissional, como já descrito por Snell-Hornby (1997:270): "Traduzir no sentido tradicional de simples transcodificação lingüística tem cada vez menos lugar na aldeia global de hoje, pelo menos enquanto atividade profissional."

O tradutor de hipertextos atua como um consultor cultural, lingüístico e técnico. Analogamente a Todesco (1998:268), que denomina o leitor de hipertextos "hiperleitor-autor" ou "hiper-redator", afirmo que o tradutor de hipertextos é um hipertradutor.

\section{REFERÊNCIAS BIBLIOGRÁFICAS}

BEAUGRANDE, R., DRESSLER, W. Introduction to text linguistics. N.Y.: Long., 1981.

ECKKRAMMER, E., EDER, H. (Cyber)Diskurs zwischen Konvention und Revolution. Frankfurt/M.: Lang, 2000.

GIL, A. Sprachvergleich anhand elektronischer Texte. Französischdeutsche Hypertexte im Kontrast. In: REINART, S. et al. (Eds.). Sprachvergleich und Übersetzen: Französisch und Deutsch. Bonn: Romanistischer Verlag, 1999a. p.281-293. 
----- Übersetzen im Internet. Der mehrsprachige elektronische Text. Eine romanistische Studie: In: GIL, A. et al. (Eds.). Modelle der Translation Grundlagen für Methodik, Bewertung, Computermodellierung. Frankfurt/M.: Lang, 1999b. p.79-95.

MARCUSCHI, L. Linearização, cognição e referência: o desafio do hipertexto. In: GUIMARÃES, E. et al. (Eds.). Línguas e instrumentos lingüísticos 3. Campinas: Pontes, 1999. p.21-45.

MATEUS, M., BRITO, A., DUARTE, I., FARIA, I. Gramática da língua portuguesa. Lisboa: Caminho, 1992.

TODESCO, R. Effiziente Informationseinheiten im Hypertext. In: STORRER, A. et al. (Eds.), Hypermedia für Lexikon und Grammatik. Tübingen: Narr, 1998. p.265-275.

SNELL-HORNBY, M. 'Jack McWorld, M.A.': Translatoren um die Jahrtausendwende. In: GRBIC, N. et al. (Eds.). Text - Kultur Kommunikation. Tübingen: Stauffenburg, 1997. p.265-279.

STORRER, A. Was ist ,hyper' am Hypertext?. In: KALLMEYER, W. (Ed.), Sprache und neue Medien. Berlin/N.Y.: de Gruyter, 2000. p.222249. 